\title{
Relationship between academic self-efficacy, performance and anxious and depressive symptoms in emerging adult college students
}

ANA GUTIÉRREZ GARCÍA*

Universidad Veracruzana - México

MARÍA LANDEROS VELÁZQUEZ ${ }^{* *}$

Universidad Veracruzana - México

Recibido el 17-12-19; primera evaluación el 06-06-20; segunda evaluación el 25-06-20; aceptado el 30-08-20

\begin{abstract}
The objective of the present investigation was to explore the levels of academic self-efficacy and their relationship with performance, anxiety and depression in a sample of emerging university adults. 114 students between 17 and 30 years of age $(S D=2.12)$ answered the Academic Behavior Self-efficacy Scale, the Diagnostic Questionnaire for Depressive Disorders and an Anxiety Inventory. For academic performance, the average grade for high school education, the university entrance exam and the first semester of university were considered. The analysis of the measurement of the levels of each of these variables and their correlation indicated that the respondents who had low academic self-efficacy when entering university had the lowest academic performance during high school and a high level of anxiety upon entering university without symptoms of depression.
\end{abstract}

Keywords: anxiety; emerging adulthood; academic performance; self-efficacy.

\footnotetext{
* Investigadora del Instituto de Neuroetología de la Universidad Veracruzana, México. Imparte cátedra de Psicobiología y Procesos Psicológicos Básicos en la Facultad de Psicología, Universidad Veracruzana, y de Neurobiología de la conducta en el Posgrado de Neuroetología. Miembro del Sistema Nacional de Investigadores. Psicóloga experimental, con doctorado en Neurociencias por la UNAM. Su campo de especialización abarca el estudio de las emociones, a través de una aproximación conductual y neurobiológica. Correo electrónico: angutierrez@uv.mx. https://orcid.org/0000-0003-1616-6390

** Psicóloga egresada de la Facultad de Psicología de la Universidad Autónoma de México (UNAM). Magíster en Educación por la Universidad Pedagógica Veracruzana. Doctora en Educación por la Universidad IVES. Su campo de interés y de especialización es la Educación Superior. Realizó publicaciones en temas de trayectorias escolares. Cuenta con más de veinte ańos de experiencia docente en Educación Superior en la Universidad Veracruzana. Correo electrónico: 1_maria_gerarda@hotmail.com https://orcid.org/0000-0001-5853-7618
} 


\section{Relación entre autoeficacia académica, rendimiento y sintomatología ansiosa y depresiva en adultos emergentes universitarios}

\section{RESUMEN}

El objetivo de la presente investigación fue explorar los niveles de autoeficacia académica y su relación con el rendimiento, la ansiedad y la depresión en una muestra de adultos emergentes universitarios. 114 estudiantes entre 17 y 30 años $(\mathrm{DE}=2.12)$ respondieron a la Escala de Autoeficacia en Comportamientos Académicos, al Cuestionario de diagnóstico de los trastornos depresivos y a un Inventario de Ansiedad. Para el rendimiento académico se consideró el promedio de calificaciones del bachillerato, del examen de ingreso a la universidad y del primer semestre universitario. El análisis de la medición de los niveles de cada una de estas variables y su correlación indicó que los encuestados que tuvieron baja autoeficacia académica al ingresar a la universidad tuvieron el menor rendimiento académico durante el bachillerato y un alto nivel de ansiedad a su ingreso a la universidad, sin síntomas de depresión.

Palabras clave: ansiedad; adultez emergente; rendimiento académico; autoeficacia.

\section{Relaçáo entre an auto-eficácia académica, desempenho e sintomas de ansiedade e depressáo em estudantes universitários adultos emergentes}

\section{RESUMO}

A presente investigação teve como objetivo explorar os níveis de auto-eficácia académica e a sua relação com o desempenho, ansiedade e depressão numa amostra de adultos universitários. 114 estudantes entre os 17 e os 30 anos (DP = 2.12) responderam à Escala de Autoeficácia em Comportamento Académico, ao Questionário de Diagnóstico de Patologias Depressivas e ao Inventário de Ansiedade. Para classificar o desempenho académico, a média das notas do ensino secundário, o exame de acesso à Universidade e o primeiro semestre universitário foram considerados. A análise dos valores de cada variável e a sua correlação indicaram que os participantes com baixos níveis de auto-eficácia académica aquando da sua entrada na universidade, também apresentaram um desempenho académico inferior durante o ensino secundário, e níveis elevados de ansiedade após a entrada na universidade sem sintomas de depressão.

Palavras-chave: ansiedade; início da maturidade; desempenho académico; auto-eficácia. 


\section{INTRODUCTION}

Emerging adulthood comprises the stage of transition between adolescence and young adulthood (approximately between 18 and 29 years of age), which also coincides with the entry of young people into higher education (Arnett, 2016). The entry of emerging adults into the university brings opportunities and challenges because many young people must become independent of their parents, which means that sometimes they must combine school with work or establish new social roles (Gutiérrez \& Park, 2015; Peer, Hillman, \& Van Hoet, 2015). The changes that are produced during this stage, together with the increase in academic demands, can hinder the successful adaptation of emerging adults to the university, and can generate high levels of stress, dissatisfaction or low academic performance (Arnett, Žukauskienè, \& Sugimura, 2014). Factors such as self-efficacy are relevant in facing this transition stage (Krypel \& King, 2010).

In the university context, self-efficacy is involved in the judgments that the student makes about his or her abilities to organize and execute the different actions required (Sanjuán, Pérez, \& Bermúdez, 2000). Self-efficacy is an important cognitive mediator of performance (Mafla, Divaris, HerreraLópez, \& Helf, 2019) because self-efficacy favors cognitive processes; that is, when students have an adequate level of self-efficacy, they can generate beliefs of expectation value, which would allow them to anticipate their actions and emotions in different academic situations (Doménech-Betoret, AbellánRoselló, \& Gómez-Artiga, 2017).

Further, self-efficacy has some relation with metacognition, a process that allows monitoring and controlling cognitive processes and executive functions (Gutiérrez-García, Huerta-Córtes, \& Landeros-Velázquez, 2020; Medina, Castleberry, \& Persky, 2017). Students with low self-efficacy often make more mistakes in metacognition tasks during neuropsychological tests, which result from the underestimation made by the student in relation to his or her judgment of personal performance based on the prediction and monitoring of his or her own performance (Gutiérrez-García \& Landeros-Velázquez, 2017). This is relevant because self-efficacy influences how people feel, think and act (Bandura, 1997). A high sense of self-efficacy facilitates information processing and cognitive performance in different contexts, including decision making and academic achievement (Mafla et al., 2019).

Since self-efficacy is the self-perception that each individual has over his or her abilities (Bandura, 1997), students with a high belief in self-efficacy tend to interpret academic work as a challenge to be faced 
in an efficient manner, whereby they trust their own skills, are more persistent, and make efficient use of acquired knowledge and skills (Honicke \& Broadbent, 2016). All these positive factors are related to high academic performance (Denovan \& Macaskill, 2013; Khan, 2013; Mafla et al., 2019). In contrast, a low perception of self-efficacy is frequently linked to a high rating on an anxiety index (Gutiérrez-García \& Landeros-Velázquez, 2018), which in turn is related to low academic performance (Onyeizugbo, 2010). In addition, when certain situations exceed the individual's abilities, the levels of self-efficacy decrease, and this can be a trigger for anxiety (Morales-Rodríguez \& Pérez-Mármol, 2019), such as those that occur during the transition stage of the emerging adult (Arnett, 2016).

Some epidemiological surveys have reported that anxiety disorders are more common than depression in adults (Ramos \& Stanley, 2017), and that anxiety in the last three decades has become the seventh rated aggravated condition of all diseases in the world (Rose \& Devine, 2014). More than half of emerging adults often experience anxiety and depression, with a higher prevalence among women (Gomes, Soares, Kieling, Rohde, \& Gonçalves, 2019). University students have difficulty processing the changes that their age implies, especially if they are without adequate social support (Arnett et al., 2014). Thus, the present study was aimed at exploring the relationship between the levels of self-efficacy, academic performance, anxiety and depression in a sample of students who were recently entering a university career. It is hypothesized that low levels of academic self-efficacy contribute to high levels of anxiety and depression that influence the academic performance of students in their transition to higher education.

\section{THEORETICAL FRAMEWORK}

\subsection{Self-efficacy and academic performance}

In terms of consistency, it can be assumed that self-efficacy is an important factor in academic performance because higher education students with greater efficiency, expectations and academic performance attend university with less difficulty and obtain the highest scores in the first year of their higher education (Chemers, Hu, \& Garcia, 2001). In a recent systematic review of the literature by Honicke and Broadbent (2016), the results of 51 studies indicate a moderate positive relationship between academic self-efficacy and academic performance. Even college students in the freshman year, who were surveyed both at the end of their first and last quarter of the year, had high 
academic self-efficacy and high grades, and this has been related to higher average high school grades (Chemers et al., 2001).

\subsection{Measurement of self-efficacy and its relationship with gender}

On the other hand, the results of other investigations have described gender differences with respect to perception of academic self-efficacy (Asbún \& Ferreira, 2004; Peinado-Pérez, Zueck-Enríquez, Gastélum-Cuadras, RangelLedezma, \& Blanco-Vega, 2015). In general, it has been reported that women, in comparison to men, perceive themselves as having higher levels of academic self-efficacy (Blanco-Vega, Ornelas-Contreras, Aguirre-Chávez, \& Guedea, 2012). The study of the influence of gender in the context of academic selfefficacy is interesting, starting from the fact that self-efficacy expectations constitute one of the main determinants of academic differences and professional decision-making (Bandura, 1999).

Many of these differences relate to the culture and socialization processes that lead women and men to different roles and perceptions of the tasks, activities, studies and occupations that are most appropriate for each gender. But these gender differences are not only related to self-efficacy, because they are also related to emotional aspects. The involvement of steroidal hormones in the emotional response is well known and women throughout the hormonal cycle usually have temporary states of irritability, anxiety or even depression (Albert, Pruessner, \& Newhouse, 2015). Therefore, it is of interest to determine to what extent these gender differences influence not only anxiety levels but also the response to self-efficacy in educational settings.

\section{METHOD}

Participants were informed about the objectives of this study, and it was conducted according to the Declaration of Helsinki of the Wold Medical Association. The research protocol was approved by the Ethics Committee (registration number CEI-PSI/002/2015) of the institution where the research was conducted. All participants in the study sample agreed to participate voluntarily and each voluntarily signed an informed consent.

\subsection{Participants}

A non-probabilistic convenience sampling was carried out. From the total of 183 students enrolled in the 2015 intake to the first semester at a public university in Mexico, only a total of 114 students voluntary participated in 
the present study. Three women and five men were removed from the database because they were definitively discharged within the first month following admission, and 61 individuals decided not to participate, hence they were excluded from the present study. Therefore, a total of 114 students were included, 66 women $(58 \%)$ with average age of $18.6(\mathrm{SD}=1.52)$ having an age range of 17 to $25 \mathrm{yrs}$, and 48 men (42\%), with an age range of 17 to $30 \mathrm{yrs}$ $(19.5, \mathrm{SD}=2.66)$, averaging 19.0 yrs $(\mathrm{SD}=2.12)$.

\subsection{Instruments}

\subsubsection{Self-Efficacy Scale in Academic Behaviors}

The Self-Efficacy Scale in Academic Behaviors (EACA is the Spanish acronym) was designed by Blanco-Vega, Marín, Enríquez, and Cuadras (2011) and it was chosen for the present study. It is a computer-assisted self-administering survey with a Likert scale having 16 items. The respondent answers are on a scale of 0 to $10(0=$ Of Little Importance; $10=$ Absolutely Essential $)$. The Index of Global Academic Self-Efficacy was evaluated, being obtained from the responses to the perceived capacity scenario, that is, whatever the student believes they are capable of at the present time. The analysis of the psychometric properties of the EACA (goodness of fit index, GFI $=0.924$; root mean square error of approximation, RMSEA $=0.086$, with Cronbach's $\alpha>0.80$ ), has shown that it is viable and adequate according to the psychometric requirements established when the informants are students and has congruent validity and good construct validity. On the other hand, the participants are accustomed to the scale of grades from 0 to 10 , since they have already been evaluated by the educational system of Mexico (Peinado-Pérez et al., 2015). Thus, a higher score will indicate greater self-efficacy, while a lower score will indicate less self-efficacy.

\subsubsection{Questionnaire for the diagnosis of depressive disorders}

The Questionnaire for the Diagnosis of Depressive Disorders (hereinafter, QDDD; Spanish acronym is CDCD), that was standardized by CalderonNarváez (1997), consists of 20 items that explore more frequent signs and symptoms of depression within the socio-cultural environment. It has been determined that the questionnaire has a high reliability in the general population, involving individuals of different levels of education and age. The instrument is constructed according to the Likert scale with four response options $(0=$ 'nothing' to $3=$ 'a lot'). The Likert scale has been standardized 
in Mexico with a reliability level of Cronbach's $\alpha$ of 0.86 and congruent validity. Scores of 20 to 35 indicate a normal state, scores of 36 to 45 indicate an anxiety reaction; scores of 46 to 65 indicate medium depression, and scores of 66 or more indicate severe depression. This questionnaire has proven very useful in obtaining information about the prevalence of depression, to be easy to understand, to have quick implementation and to objectively correspond to the sociocultural reality of people.

\subsubsection{State-Trait Anxiety Inventory}

The STAI (the Spanish acronym is IDARE; the translated/validated version of the STAI as used in Mexico, Spielberg \& Díaz-Guerrero, 1975) consists of two self-report scales, designed to measure anxiety using the State Anxiety Scale (STAI-S [IDARE-E, Spanish]) which measures the current state of anxiety (i.e., symptoms of anxiety that a person experiences under a specific situation), and a trait or personality characteristic (STAI-T [IDARE-R, Spanish]) which measures the long-term state of anxiety (i.e., people usually experience anxiety symptoms as a personality trait). Both scales consist of 20 items that are scored on a Likert scale from 0 (= 'nothing') to 3 (= 'a lot'). The STAI has high consistency, validity, and reliability (Cronbach's $\alpha=0.83$ for the STAI-T subscale and 0.92 for the STAI-S subscale), in which its elements and scales are closely related to the constructs of the instrument. The scores are classified as follows: 20-31 (very low anxiety), 32-43 (low anxiety), 44-55 (moderate anxiety), and 56-6 7 (high anxiety), and 68-80 (very high anxiety). STAI-S validity was originally derived from testing in situations characterized by high state stress including classroom examinations, military training programs, etc. Like other measures of anxiety, the STAI is also highly correlated with depression and, in some studies, the STAI did not differentiate anxious from depressed patients (Julian, 2011) and has good convergent validity (Kvaall, Ulstein, Nordhus, \& Engedal, 2005).

\subsection{Academic performance}

The State Exam for Admission to Higher Education (EXANI-II, Spanish acronym) is an instrument that evaluates the potential academic aptitude that the aspiring individual has in order to initiate studies at the higher education. EXANI-II is carried out by the National Center for the Evaluation of Higher Education (CENEVAL, Spanish acronym), which is dedicated to evaluating schools and universities, among others. This admission exam includes 100 questions and assesses knowledge in the areas of Mathematical Reasoning, 
Analytical Reasoning, Language Structure and Reading Comprehension, which are considered predictive indicators. The maximum time to solve the exam is 3 hours.

In addition to the score obtained in the EXANI-II, the high school GPA (i.e., average grade the students obtained during high school education) is required. Finally, student academic performance was measured using the official end of first university semester grades, which were from 0.0 to 10.0 points; lack of approval of a course was indicated with a grade $\leq 5.0$.

\subsection{Procedure}

The students were invited to participate in the present study during the first month after entering university. The three scales were applied in a session of approximately $25 \mathrm{~min}$, by means of a personal computer. At the beginning of each session, a brief introduction was presented on the importance of this research and how to access the survey instrument. Before responding to the three instruments, the participants were asked some questions related to their history of neurological or psychiatric disorders, their medical condition and illegal drug and alcohol use, with the sole purpose of knowing some general characteristics of the study sample. Response instructions appeared on the screens before the first initiation of the instrument. The order of presentation of the scales was: first, EACA; second, QDDD; third, STAI-S and STAI-T. The data of all the variables were obtained through the answers of the students.

\subsection{Statistical analysis}

To develop the databases of the results, Excel software for data voids and the statistical package Sigma 12.0 were used. The first analysis consisted in determining some difference attributable to gender in the scores obtained in academic self-efficacy, as in CDDD, STAIT-S and STAIT-T, using a t-Student.

Subsequently, the data were divided into three groups to classify the students according to their perceived level of self-efficacy. The grouping was carried out as follows, on the index of perceived self-efficacy obtained from EACA: Group A: scores of 1 to 7.4; Group B: scores of 7.5 to 8.9; Group C: scores of 9.0 to 10.0. This classification was based on the fact that in the Mexican educational system, the scores have a rating in the range 0-10.0. A general GPA of 5.9 is considered a failing grade, while ratings of 6.0 to 7.4 are considered a low or sufficient grade; scores of 7.5 to 8.9 are considered a moderate or satisfactory grade; the scores of 9 to 10 are considered a high grade (Gutiérrez-García \& Landeros-Velázquez, 2018). In addition, EACA 
yield a total average score, which fails to distinguish between students who obtain low scores and students who obtain high scores, of the same sample. For this reason, an arbitrary classification was made, which in a previous work permitted, through the obtaining of the perceived (current) self-efficacy score, to form subgroups by considering the scores of students with low, intermediate and high self-efficacy, of the same sample. This type of classification can be very useful for organizing general scores when conducting self-efficacy profiles in academic behaviors in university students and the participants are accustomed to the scale of grades from 0 to 10 , since they have already been evaluated by the educational system of Mexico, a criterion used by the author of EACA (Blanco-Vega et al., 2011).

From this classification, a one-way analysis of variance (ANOVA) was undertaken. In case the data did not follow a normal distribution, the data were ranked. The Holm-Sidak method was used as a post hoc test. The comparisons of the average grades obtained during high school were compared with those obtained during the first semester of university, using a $t$-paired test.

A Pearson correlation analysis was also carried out. Finally, a multiple linear regression analysis was performed while considering the self-efficacy scores as the dependent variable and the academic performance data set and the aforementioned instruments as predictor variables. The level of statistical significance was established at $p<0.05$. The data are represented as the mean \pm the standard error of the mean.

\section{RESULTS}

The sample had an average age of 19 years. One third of these students admit to drinking alcohol in general (women: 16, 14\% and men: 13, 11.4\%). The reported psychiatric/neurological diseases included generalized anxiety disorder, depression, schizophrenia, epilepsy, and others (not shown in the table). The medical conditions reported included asthma, clinical hyperthyroidism, gastrointestinal problems, and vitiligo (Table 1).

Table 1. Descriptive statistics for the sample of 114 undergraduate Students

\begin{tabular}{lll}
\hline \multicolumn{1}{c}{ Characteristic } & Mean $(\mathrm{SD})$ & $\%(\mathbf{n})$ \\
\hline Age (years) & $19.0(2.12)$ & \\
\hline Gender & & \\
Male & & $66(58)$ \\
Female & & $48(42)$ \\
\hline
\end{tabular}




\begin{tabular}{lc}
\hline \multicolumn{1}{c}{ Characteristic } & Mean (SD) \\
\hline Alcohol drinking & $85(74.6)$ \\
No & $29(25.4)$ \\
Yes & \\
\hline Psychiatric/neurological Illness & $96(84.2)$ \\
No & $18(15.8)$ \\
Yes & $103(90.3)$ \\
\hline Major medical problems & $11(9.7)$ \\
No & \\
Yes & $107(93.9)$ \\
\hline Drug use & $7(6.1)$ \\
No & \\
Yes & \\
\hline
\end{tabular}

Note. $\mathrm{SD}=$ standard deviation.

Source: General descriptive data obtained from the sample of students. Authors' elaboration.

\subsection{Gender differences}

To determine some difference in the levels of academic self-efficacy that are attributable to gender, an initial comparison was made between women and men. There were no significant differences by gender in the global scores of perceived self-efficacy $(\mathrm{t}=-0.717,112 d f, p=0.475$; women: $8.1 \pm 0.10$ and men: $8.2 \pm 0.14)$. Nor were significant differences found in the scores obtained in CDCD attributable to gender $(\mathrm{t}=-1,274,112 d f, p=0.205$; women: $30.0 \pm 0.90$ and men: $32.2 \pm 1.58)$. When comparing the scores obtained in STAI-S by gender $(\mathrm{t}=0.219,112 d f, p=0.827$; women $48.4 \pm 1.27$ and men: $47.9 \pm 1.61)$; and STAI-T $(\mathrm{t}=-0.3 .380,112 d f, p=0.704$; women 47.9 \pm 1.25 and men: $48.7 \pm 1.61$ ), no significant differences were found either. Therefore, it was decided to collect the sample and make the comparisons only with the criteria of classification of groups according to their level of perceived self-efficacy.

\subsection{Perceived self-efficacy}

The percentage of students that were distributed in the different groups according to the perceived level of self-efficacy was Group A: sufficient $(n=23$, $20.2 \%)$; group B: satisfactory $(n=68,59.6 \%)$ and Group C: High $(n=23$, $20.2 \%$ ). 
The one-way ANOVA indicated significant differences attributable to the level of perceived self-efficacy $\left(\mathrm{F}_{2,111}=190.0, p<0.001\right)$. The lowest level of self-efficacy (sufficient) was for group A; followed by group B with a level of intermediate self-efficacy, while group $\mathrm{C}$ had the highest self-efficacy levels; see Fig. 1A.

\subsection{QDDD}

Significant differences were found attributable to the level of perceived selfefficacy in the QDDD $\left(\mathrm{F}_{2,111}=4.090, p<0.01\right)$. The students of group A with low perceived self-efficacy had the highest scores in this scale, corresponding to an anxiety reaction, followed significantly by group B and finally, group C obtained low scores in QDDD, indicating a normal state of mind. Fig. 1B.

\subsection{STAI-S}

The one-way ANOVA indicated significant differences attributable to the level of perceived self-efficacy in STAI-S scores among the three groups $\left(\mathrm{F}_{2,111}=\right.$ $8.272, p<0.001)$. Students in group A with low perceived self-efficacy had the highest scores in this scale, corresponding to moderate to high anxiety, followed significantly by group B (moderate range anxiety) and finally, group $\mathrm{C}$ which obtained the lowest scores, indicating a low level of anxiety. Fig. 1C.

\subsection{STAI-T}

The one-way ANOVA showed that the scores on the STAI-S were significantly different among the three groups $\left(\mathrm{F}_{2,111}=6.433, p<0.002\right)$. Students in group A with low perceived self-efficacy had the highest scores in this scale, corresponding to moderate to high anxiety, followed significantly by group B and finally, group C, which obtained the lowest scores, suggesting a low anxiety state. Fig. 1D.

\subsection{Scores obtained in the university entrance exam (EXANI-II)}

No differences attributable to the classification group were found according to the level of perceived self-efficacy in scores obtained in the EXANI-II $\left(\mathrm{F}_{2,111}=\right.$ $0.272, p=0.762$ ): Group A: $69.9 \pm 1.89$; Group B: $70.3 \pm 0.88$; and Group C: $70.0 \pm 1.68)$. 
Figure 1. Score obtained in perceived self-efficacy, CDDD and STAIT

(A)

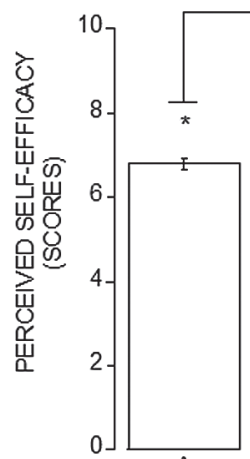

A

(c)
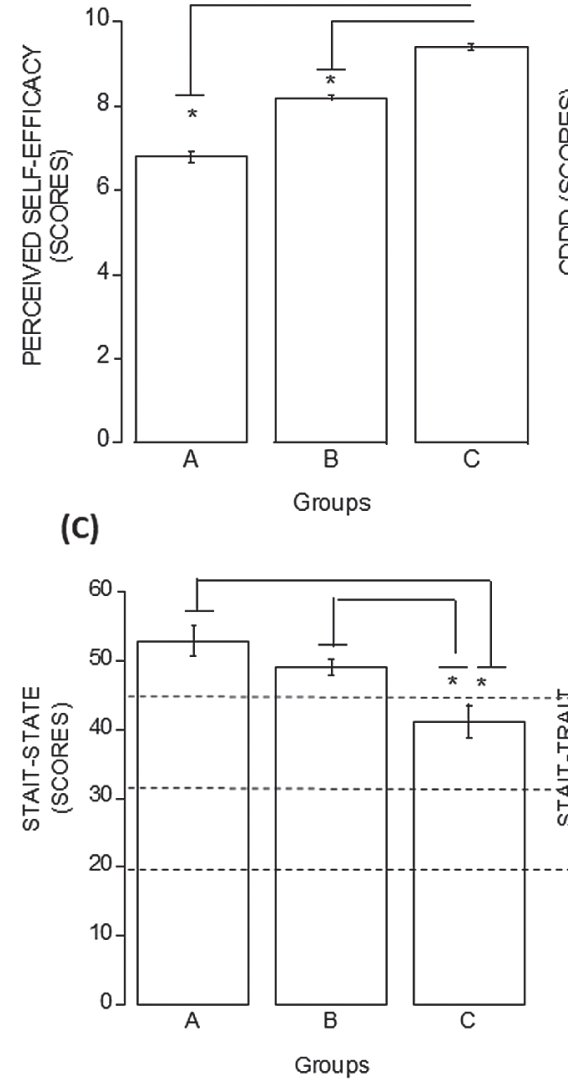

Groups
(B)

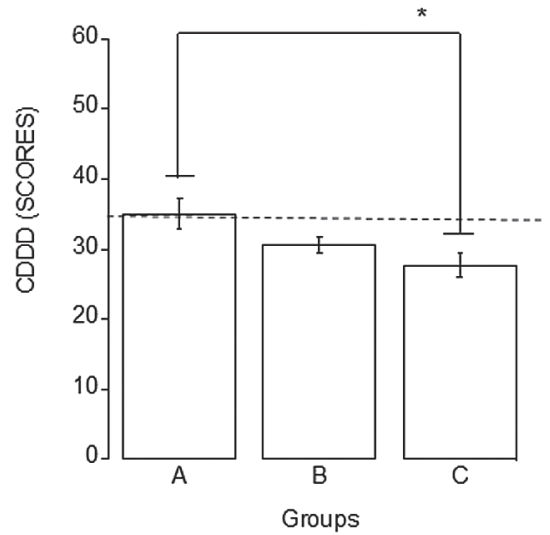

(D)

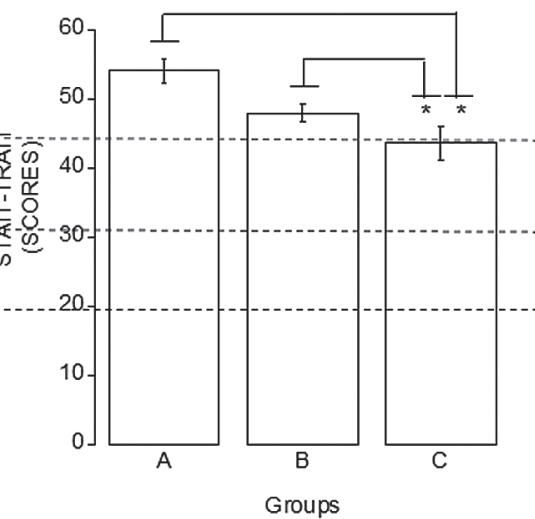

Source: (A) Score obtained in perceived self-efficacy. The lowest level of self-efficacy was for group A, followed by group B and group C had the highest self-efficacy levels. (B) Scores obtained in the QDDD. The students of group A with low perceived self-efficacy had the highest scores in this scale, corresponding to an anxiety reaction. Group $\mathrm{C}$ obtained low scores in QDDD, indicating a normal state of mind. The blue dotted line indicates the index of the scale scores within normal limits $(<35)$. (C) State-trait anxiety inventory-S scores. Students in group A with low perceived self-efficacy had the highest scores in this scale, corresponding to moderate to high anxiety. Group C which obtained the lowest scores, indicating a low level of anxiety. (D) State-trait anxiety inventory-T. Significant differences were found among groups. Group A had the highest scores in this scale, corresponding to moderate to high anxiety. $\left({ }^{*} p<0.05\right.$, Holm-Sidak test, post hoc). The blue dotted line indicates the index of the scale scores within normal limits (20-31). The red dotted line indicates high levels of anxiety (> 46). Authors' elaboration. 


\subsection{High school grade point average (GPA)}

The one-way ANOVA indicated significant differences attributable to the level of perceived self-efficacy in GPA $\left(\mathrm{F}_{2,111}=4.418, p<0.01\right)$. The significantly lower high school GPA was obtained by students by group A with low self-efficacy $(7.9 \pm 0.16, p<0.05)$, followed by group B with intermediate self-efficacy $(8.0 \pm 0.08, p<0.05)$, while group $\mathrm{C}$ obtained the highest high school GPA $(8.5 \pm 0.13, p<0.05)$; see Fig. 2 .

\subsection{GPA in the first university semester}

No significant differences attributable to level of perceived self-efficacy of the first university semester $\left(\mathrm{F}_{1,111}=0.856, p=0.427\right)$. Group A: with low selfefficacy, obtaining a GPA at the end of the semester $(7.6 \pm 0.32)$ equal to that of group B: intermediate self-efficacy $(7.6 \pm 0.21)$. Group C: with high selfefficacy, obtained a higher GPA, although it was statistically non-significant when compared with the other two groups $(8.1 \pm 0.16)$.

\subsection{Comparison between high school grade point average (GPA) and GPA in the first university semester}

The GPA obtained in high school was compared with the GPA obtained in the first university semester for group A using $t$-paired. Considering the total sample, without classification by groups, the total average high school grade was $8.1 \pm 0.06$, while GPA in the first university semester was $7.7 \pm 0.14$ $(\mathrm{t}=2,847,113 d f, p<0.005)$.

In group $A$, no significant differences were found between the GPA obtained in the high school compared with that obtained in the first university semester $(7.9 \pm 0.16$ vs. $7.62 \pm 0.31 ; \mathrm{t}=0.922,22 d f, p=0.367)$. On the other hand, it was found that students belonging to group B had significantly lower grades during their first university semester $(7.65 \pm 0.21)$ compared to the grade obtained during their high school period $(8.0 \pm 0.08 ; \mathrm{t}=2.195$, $67 d f$, $p<0.032)$. In the case of group C, which had the highest levels of perceived self-efficacy, scores during the first semester $(8.1 \pm 0.16)$ were lower than those of the high school period $(8.5 \pm 0.13)$, but these differences did not reveal any statistical significance $(\mathrm{t}=1,949,22 d f, p=0.064)$, see Fig. 2 . 


\section{Figure 2. Score obtained in the high school GPA and first year} of university GPA

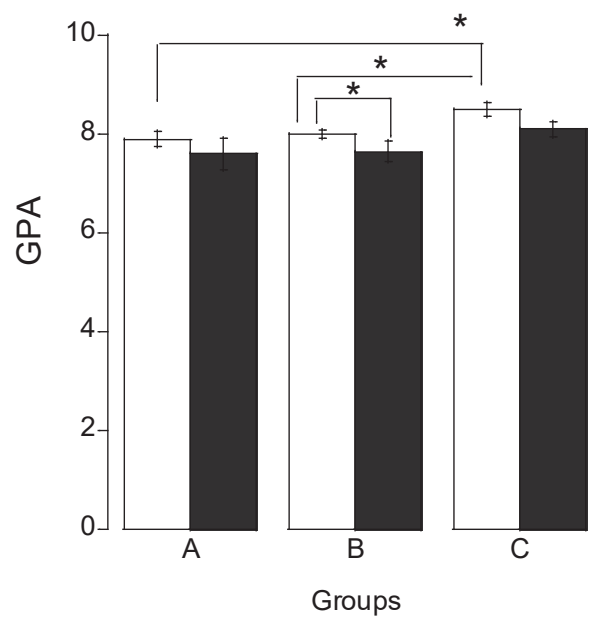

Source: Score obtained in the high school GPA (white bars) and first year of university GPA (hatched bars). Group C obtained the highest marks during high school GPA and is the group with the highest levels of academic self-efficacy $\left({ }^{*} p<0.05\right.$, Holm-Sidak post hoc test). The three groups of students upon admission to college lowered their academic performance with respect to their high school GPA. This change was observed more significantly in-group B ( ${ }^{*} p<0.032$, t-paired). Authors' elaboration.

\subsection{Correlations between the variables in the study}

According to the Pearson correlation, a significant low positive correlation was found between perceived self-efficacy and high school GPA. That is, most of the young people who obtained the highest scores in perceived self-efficacy also obtained a higher high school GPA, but no correlation was found between the score obtained in the EXANI-II as with the University GPA that was obtained in the first semester. On the other hand, the perceived self-efficacy had a significant inverse correlation with the scores obtained in QDDD, STAI-S and STAI-T. A positive correlation was also found between the high school GPA, the University GPA that was obtained during the first semester, and with the general university entrance examination GPA. Scales that measured emotional states had significantly high positive correlations between them (See Table 2). 
Table 2. Pearson correlations between the scores obtained in the self-efficacy, average, and anxiety scales

\begin{tabular}{lcccccc}
\hline \multicolumn{1}{c}{ Variable } & HS-GPA & FS-GPA & EXANI-II & QDDD & STAI-S & STAI-T \\
\hline Self-efficacy & $0.268^{*}$ & 0.138 & 0.098 & $-0.256^{*}$ & $-0.336^{* *}$ & $-0.315^{* *}$ \\
HS-GPA & - & $0.318^{* *}$ & -0.035 & -0.147 & -0.157 & -0.097 \\
FS-GPA & - & - & $0.202^{+}$ & 0.035 & 0.075 & 0.051 \\
EXANI-II & - & - & - & 0.113 & 0.566 & 0.043 \\
QDDD & - & - & - & - & $0.686^{* *}$ & $0.809^{* *}$ \\
STAI-S & - & - & - & - & - & $0.769^{* *}$ \\
STAI-T & - & - & - & - & - & - \\
\hline
\end{tabular}

${ }^{+} p<0.01 ;{ }^{*} p<0.001 ;{ }^{* *} p<0.0001$; Abbreviations: HS-GPA, high school grade point average; FS-GPA, first semester grade point average; State Exam for Admission to Higher Education (EXANIII); QDDD, Questionnaire for the Diagnosis of Depressive Disorders; STAI-S, State Anxiety Scale; STAI-T trait or personality characteristic.

Source: Data obtained from the correlations between the scores. Authors' elaboration.

Multiple regression analysis indicated that the predictors explained $43.6 \%$ of the variance in self-efficacy $\left(\mathrm{R} 2=0.436, \mathrm{~F}_{(5,108)}=4.197, p<0.001\right)$. The main effect was from the scores obtained on STAI-S $(\beta=-0.0293$, $\mathrm{t}=-3.775, p<0.001)$, STAI-T $(\beta=-0.0277, \mathrm{t}=-3.513, p<0.001)$, QDDD $(\beta=-0.0263, \mathrm{t}=-2.806, p<0.006)$ and the average grade the students obtained during high school education (HS-GPA: $\beta=0.343, \mathrm{t}=2.942, p<0.004$ ). There was no main effect of Scores obtained in the university entrance exam (EXANI-II: $\beta=0.0118, \mathrm{t}=1.050, p=0.296$ ) and first semester grade point average (FS-GPA: $\beta=0.0830, \mathrm{t}=1.471, p=0.144$ ). Taken together, the results of the regression analysis indicated that students with high levels of anxiety have low levels of self-efficacy, while high academic performance during high school predicts a good level of academic self-efficacy when entering university, but not during the university.

\section{Discussion}

The present study was aimed at measuring the levels of self-efficacy, academic performance, anxiety and depression in students who recently entered university in order to determine a possible relationship of these variables that determines the nature of their transition to higher education. 
The sample as a whole obtained satisfactory average scores regarding perceived self-efficacy, which were similar to those scores reported when using the same scale for other samples of 1) Mexican university students (e.g., Blanco-Vega et al., 2011, León-Hernández, González-Escobar, GonzálezArratia, \& Barcelata, 2019), 2) Colombians (Mafla et al., 2019), and 3) Spaniards (Viciana, Cervelló, \& Ramírez, 2007). However, in the present study there were students with low scores of perceived self-efficacy compared to other students who had scores above 9.0. Therefore, the main contribution of the present study is that it is possible, via the achievement of the perceived self-efficacy score, to form subgroups when considering the scores of students with low, intermediate and high self-efficacy. This proposal to classify groups according to perceived self-efficacy may be relevant and should be considered in the evaluation of academic behaviors, thus identifying different levels of perceived self-efficacy using the EACA scale, as other researchers are already doing (Dominguez-Lara \& Fernández-Arata, 2019; León-Hernández et al., 2019).

Although some studies have described significant differences attributable to gender in perceived self-efficacy (Viciana et al., 2007; Khan, Cansever, Avsar, \& Acemoglu, 2013), other studies have not identified gender differences (Al-Kfaween, 2010; Shkullaku, 2013; Williams \& Takaku, 2011). In the present study, the absence of significant gender differences in academic self-efficacy indicates that Mexican students, both men and women, have the same levels of self-efficacy.

Several studies have already linked academic self-efficacy and academic performance (Adeyemo, 2007; Al-Harthy \& Was, 2013; Tenaw, 2013; Khan, 2013; Alyami et al., 2017), and the present research confirms that high levels of self-efficacy are related to higher levels of academic achievement in terms of qualifications (Akram \& Ghazanfar, 2015). In the present study, it is significant that after completing the first university semester, the average scores obtained were not related to the levels of self-efficacy reported at the beginning of the semester. There was also no relationship between the levels of self-efficacy and the scores obtained in the general entrance examination to the university. In particular, the transition from one educational level to another in a sensitive-emergent period can confront the students with some difficulties, hence it is necessary to train teachers to improve the self-efficacy of their students by adopting different strategies (Akram \& Ghazanfar, 2015), for example, through efficient systems of admission and induction of university students that incorporate support, and also support programs (DoménechBetoret et al., 2017). 
It is possible that measuring self-efficacy at the beginning of university admission, and not at the end of the first semester of higher education, will affect the obtained results. High self-efficacy is related to high school GPAs, but not to the grades obtained in the first university semester. Galyon, Blondin, Yaw, Nall, and Williams (2012) found that self-efficacy correlated better with academic performance during the middle of a course, with no significant correlations being observed when measured during the early stages.

On the other hand, the scores obtained by the students in the depression and anxiety scales showed a high negative correlation with the scores obtained in the perceived self-efficacy scale: the lower the perceived self-efficacy, the higher the levels of anxiety. It is possible that there are two variables that occur in parallel rather than in a causal relationship. In that, it could be a critical incident occurring as part of the emergent stage that students are experiencing, given that anxiety levels are in the range of low to moderate anxiety. However, A group showed moderate to high anxiety-trait levels. The STAI was able to discern between an anxiety state and an anxiety trait. If the students classified in group A reached scores that suggest high anxiety and not only in specific situations (anxiety-state), but also as a generalized tendency to respond anxiously (anxiety-trait), then this tendency could extend for long periods of time and in all situation types, thus putting the vulnerable student at risk in their university experience.

Therefore, low self-efficacy tends to increase some emotional and social problems (Gouláo, 2014). Anxiety, suicide and alcohol abuse continue to threaten adolescent and emerging adult populations throughout the world (Arnett et al., 2014). Predominantly, the incidence of mood disorders and anxiety increases considerably in adolescence and early adulthood (Roza, Hofstra, van der Ende, \& Verhulst, 2003). In the present study, anxiety was significantly related to the QDDD, where group A also had the highest scores, suggesting an anxiety reaction rather than a depressive state. No depression was observed in any of the groups. Based on the obtained results, a population with possibilities of being vulnerable is identified, given that a high percentage $(15.8 \%$, Table 1$)$ of the sample indicates the presence of diagnosed psychiatric illness, with affective disorders being the most highly reported. The general prevalence of emotional disorders, mainly anxiety, is in the range of 4-24\% in different countries; in Mexico the range of $8.4-29.8 \%$ has been reported (Craske \& Stein, 2016; Alonso et al., 2018).

It is assumed that increasing the sense of self-efficacy helps to better control those unpleasant emotions and, therefore, to diminish the likely harmful results. Other cross-sectional studies have suggested that self-efficacy has an 
important relationship with the emotional states of emerging adults and that changes related to age will depend on the state of general, academic, physical and social self-efficacy (León-Hernández et al., 2019).

In parallel, assessing self-efficacy and its relation to academic performance in the early stages of university education is a reasonable endeavor. Students with no or limited previous experience of a university environment will have limited exposure to experiencing the mastery of learning within such environments, and no opportunity to develop effective beliefs in their own performance skills. Future research should provide more information on the development of selfefficacy and also promote the implementation of early intervention programs that improve self-efficacy and performance, resulting in better educational outcomes for college students that would also impact on their emotional health (Doménech-Betoret et al., 2017; Honicke \& Broadbent, 2016).

\section{Conclusion}

According to our results, perceived self-efficacy can be modified in emerging adults who change from a high school academic environment to a university education environment. The $20 \%$ of the respondents were at a low level of self-efficacy, which was significantly related to low academic performance and a high level of anxiety. Therefore, based on the results of this research, it is recommended that students be exposed to a self-efficacy intervention program, in order that they can develop the confidence to feel that they have the ability to perform really well and to deal with all the necessary academic tasks in a positive manner. This in turn will improve both academic and emotional performance of young people in a phase of transition from basic to college education. Therefore, future studies should evaluate the long term effects of educational interventions during the first university years, while taking into account self-efficacy and strategies to cope with anxiety in young emerging adults.

\section{FUNDING}

This research did not receive any specific grant from funding agencies in the public, commercial or not-for-profit sectors.

\section{DeClaration OF CONFLICTS OF INTEREST}

The authors declare that there is no conflict of interest in this work. 


\section{BibLIOGRAPHIC REFERENCES}

Albert, K., Pruessner, J., \& Newhouse, P. (2015). Estradiol levels modulate brain activity and negative responses to psychosocial stress across the menstrual cycle. Psychoneuroendocrinology, 59, 14-24. https://doi.org/10.1016/j. psyneuen.2015.04.022

Asbún, C., \& Ferreira, Y. (2004). Autoeficacia profesional y género en adolescentes de cuarto de secundaria de la zona sur de la ciudad de la Paz. Revista Ajayu, 2(1), Retrieved from http://www.ucb.edu.bo/Publicaciones/Ajayu/ v2n1/v2n1a3.html

Adeyemo, D. A. (2007). Moderating influence of emotional intelligence on the link between academic self-efficacy and achievement of university students. Psychology \& Developing Societies, 19(2), 199-213. https://doi. org/10.1177/097133360701900204

Akram, B., \& Ghazanfar, L. (2015). Self efficacy and academic performance of the students of gujrat university, Pakistan. Academic Research International, 5(1), 283-290. Retrieved from http://www.savap.org.pk/journals/ARInt./ Vol.5 (1)/2014(5.1-30).pdf

Al-Harthy, I. S., \& Was, C. A. (2013). Knowledge Monitoring, Goal Orientations, Self-Efficacy, and Academic Performance: A Path Analysis. Journal of College Teaching \& Learning, 10(4), 263-278. https://doi.org/10.19030/ tlc.v10i4.8123

Al-Kfaween, E. M. (2010). Self-efficacy Among the Students of the University and Relation to Gender and Specialization. Retrieved from www.eurojournals. com/ejsr_46_3_11.pdf

Alonso, J., Liu, Z., Evans-Lacko, S., Sadikova, E., Sampson, N., Chatterji S, ... \& Thornicroft, G. (2018). Treatment gap for anxiety disorders is global: Results of the World Mental Health Surveys in 21 countries. Depress Anxiety, 35(3), 195-208. https://doi.org/10.1002/da.22711

Alyami, M., Melyani, S., Al Johani, A., Ullah, E., Alyami, H., Sundram, F., Hill, A., \& Henning, M. (2017). The Impact of Self-Esteem, Academic SelfEfficacy and Perceived Stress on Academic Performance: A Cross-Sectional Study of Saudi Psychology Students. European Journal of Educational Sciences, EJES, 4(3), 51-63. https://doi.org/10.19044/ejes.v4no3a5

Arnett, J. J., Žukauskienè, R., \& Sugimura, K. (2014). The new life stage of emerging adulthood at ages 18-29 years: Implications for mental health. The Lancet Psychiatry, 1(7), 569-576. https://doi.org/10.1016/ S2215-0366(14)00080-7

Arnett, J. J. (2016). The Oxford handbook of emerging adulthood. New York, NY: Oxford University Press. 
Bandura, A. (1997). Self-efficacy: The exercise of control. New York, EE.UU.: W. F. Freeman.

Bandura, A. (1999). Autoeficacia: Como afrontamos los cambios de la sociedad actual. Madrid, España: Desclée de Brouwer, S. A.

Blanco-Vega, H., Marín, M. M., Enríquez, M. C., \& Cuadras, G. G. (2011). [Psychometric analysis of academic behavior selfefficacy scale in firstyear college students.] Revista Electrónica Actualidades Investigativas en Educación, 11(3), 1-27. [in Spanish] Retrieved from http://www.redalyc. org/articulo.oa?id $=44722178003$.

Blanco-Vega, H., Ornelas-Contreras, M., Aguirre-Chávez, J. F. \& Guedea, J. C. (2012). Autoeficacia percibida en conductas académicas. Diferencias entre hombres y mujeres. Revista Mexicana de Investigación Educativa, 17(53), 557-571, Retrieved from http://scielo.unam.mx/pdf//rmie/v17n53/ v17n53a11.pdf

Calderón-Narváez, G. (1997). [Un cuestionario para simplificar el diagnóstico de síndrome depresivo]. Revista de Neuro-Psiquiatría, 60, 127-135. [in Spanish] https://doi.org/10.20453/rnp.v60i2.1406

Chemers, M. M., Hu, L., \& Garcia, B. F. (2001). Academic self-efficacy and firstyear college student performance and adjustment. Journal of Educational Psychology, 93, 55- 64. https://doi.org/10.1037//0022-0663.93.1.55

Craske, M. G., \& Stein, M. B. (2016). Anxiety. Lancet, 388(10063), 3048-3059. https://doi.org/10.1016/S0140-6736(16)30381-6

Denovan, A., \& Macaskill, A. (2013). An interpretative phenomenological analysis of stress and coping in first year undergraduates. British Educational Research Journal, 39(6), 1002-1024. https://doi.org/10.1002/berj.3019

Doménech-Betoret, F., Abellán-Roselló, L., \& Gómez-Artiga, A. (2017). SelfEfficacy, Satisfaction, and Academic Achievement: The Mediator Role of Students' Expectancy-Value Beliefs. Frontiers in Psychology, 18(8), 1193. https://doi.org/10.3389/fpsyg.2017.01193

Dominguez-Lara, S., \& Fernández-Arata, M. (2019). Autoeficacia académica en estudiantes de Psicología de una universidad de Lima. Revista Electrónica de Investigación Educativa, 21, e32, 1-13. https://doi.org/10.24320/ redie.2019.21.e32.2014

Galyon, C. E., Blondin, C. A., Yaw, J. S., Nalls, M. L., \& Williams, R. L. (2012). The relationship of academic self-efficacy to class participation and exam performance. Social Psychology of Education, 15, 233e249. https://doi. org/10.1007/s11218-011-9175-x

Gomes, A. P., Soares, A., Kieling, C., Rohde, L. A., \& Gonçalves, H. (2019). Mental disorders and suicide risk in emerging adulthood: the 1993 Pelotas 
birth cohort. Revista de Saude Publica, 53, 96. https://doi.org/10.11606/ s1518-8787.20190530012356

Goulão, M. F. (2014). The relationship between self-Efficacy and academic achievement in adults' learners. Athens Journal of Education, 1(3), 237-246. https://doi.org/10.30958/aje.1-3-4

Gutiérrez, I. A., \& Park, C. L. (2015). Emerging Adulthood, Evolving Worldviews: How Life Events Impact College Students' Developing Belief Systems. Emerging Adulthood, 3(2), 85-97. https://doi. org/10.1177/2167696814544501

Gutiérrez-García, A. G., \& Landeros-Velázquez, M. G. (2017) [Evaluation of executive functions in students with low perceived self-efficacy]. Revista Electrónica de Psicología, 20(2), 397-426 [in Spanish]. Retrieved from http://www.revistas.unam.mx/index.php/repi/article/view/60807

Gutiérrez-García, A. G., \& Landeros-Velázquez M. G. (2018) [Academic Selfefficacy and Anxiety, as a Critical Incident in Female and Male University Students]. Revista Costarricense de Psicología, 37(1), 1-25., [in Spanish]. https://doi.org/10.22544/rcps.v37i01.01

Gutiérrez-García, A. G., Huerta-Cortés, M., \& Landeros-Velazquez, M. G. (2020). Academic procrastination in study habits and its relationship with self-reported executive functions in high school students. Journal of Psychology and Neuroscience, 2(1), 1-9. Retrieved from https://unisciencepub.com/jpn-volume-2-issue-1-year-2020/

Honicke, T., \& Broadbent, J. (2016). The influence of academic self-efficacy on academic performance: A systematic review. Educational Research Review, 17, 63e84. https://doi.org/10.1016/j.edurev.2015.11.002

Julian, L. J. (2011). Measures of anxiety: State-Trait Anxiety Inventory (STAI), Beck Anxiety Inventory (BAI), and Hospital Anxiety and Depression Scale-Anxiety (HADS-A). Arthritis Care \& Research, 63 Suppl 11(0 11), S467-S472. https://doi.org/10.1002/acr.20561

Khan, A. S., Cansever, Z., Avsar, U. Z., \& Acemoglu, H. (2013). Perceived selfefficacy and academic performance of medical students at ataturk university, Turkey. Journal of the College of Physicians and Surgeons Pakistan, 23(7), 495-498. https://doi.org/07.2013/JCPSP.495498

Khan, M. (2013). Academic self-efficacy, coping, and academic performance in college. International Journal of Undergraduate Research and Creative Activities, 5(4), 1-11. https://doi.org/10.7710/2168-0620.1006

Krypel, M., \& King, D. (2010). Stress, coping styles and optimism: Are they related to meaning and education in students' lives? Social Psychology and Education, 13(3), 409- 424. https://doi.org/10.1007/s11218-010-9132-0 
Kvaal, K., Ulstein, I., Nordhus, I. H., \& Engedal, K. (2005). The Spielberger state- trait anxiety inventory (STAI): the state scale in detecting mental disorders in geriatric patients. International Journal of Geriatric Psychiatry: A journal of the psychiatry of late life and allied sciences, 20(7), 629-634. https://doi.org/10.1002/gps.1330

León-Hernández, A., González-Escobar, S., González-Arratia, N. I., \& Barcelata, B. E. (2019). Stress, self-efficacy, academic performance and resilience in emerging adults. Electronic Journal of Research in Educational Psychology, 17(1), 129-148. https://doi.org/10.25115/ejrep.v17i47.2226

Mafla, A. C., Divaris, K., Herrera-López, H. M., \& Heft, M. W. (2019). SelfEfficacy and academic performance in colombian dental students. Journal of Dental Education, 83(6), 697-705. https://doi.org/10.21815/JDE.019

Medina, M.S., Castleberry, A. N., \& Persky, A.M. (2017). Strategies for improving learner metacognition in health professional education. American Journal of Pharmaceutical Education, 81(4), 1-14. https://doi.org/10.5688/ ajpe81478

Morales-Rodríguez, F. M., \& Pérez-Mármol, J. M. (2019). The role of anxiety, coping strategies, and emotional intelligence on general perceived selfEfficacy in university students. Frontiers in Psychology, 10, 1-9. https://doi. org/10.3389/fpsyg.2019.01689

Onyeizugbo, E. U. (2010). Self-Efficacy and test anxiety as correlates of academic Performance. Educational Research, 1(10), 477-480, Retrieved from https://www.interesjournals.org/articles/selfefficacy-and-test-anxiety-ascorrelates-of-academic-performance.pdf

Peer, J. W., Hillman, S. B., \& Van Hoet, E. (2015). The effects of stress on the lives of emerging adult college students: an exploratory analysis. Adultspan Journal, 14(2), 90-99. https://doi.org/10.1002/adsp.12007

Peinado-Pérez, J. E., Zueck-Enríquez, M.C., Gastélum-Cuadras, G., RangelLedezma, Y. \& Blanco-Vega, H. (2015). Perceived self-efficacy in teamwork and entrepreneurship in university students. A Gender Study. Science Journal of Education, 3 (1), 1-5. https://doi.org/10.11648/j. sjedu.20150301.11

Ramos, K., \& Stanley, M. (2017). Anxiety Disorders in Late Life. The Psychiatric Clinic of North America, 41(1), 55-64. https://doi.org/10.1016/j. psc.2017.10.005

Rose, M., \& Devine, J. (2014). Assessment of patient-reported symptoms of anxiety. Dialogues in Clinical Neuroscience, 16(2), 197-211. 
Roza, S. J., Hofstra, M. B., van der Ende, J., \& Verhulst, F. C. (2003). Stable prediction of mood and anxiety disorders based on behavioral and emotional problems in childhood: a 14-year follow-up during childhood, adolescence, and young adulthood. American Journal of Psychiatry, 160(12), 2116-2121. https://doi.org/10.1176/appi.ajp.160.12.2116

Sanjuán, P., Pérez, A. M., and Bermúdez, J. (2000). Escala de autoeficacia general: datos psicométricos de la adaptación para población española [general selfefficacy scale: psychometric data from the adaptation to the Spanish population]. Psicothema, 12, 509-513. Retrieved from http://www.psicothema. $\mathrm{com} / \mathrm{pdf} / 615 . \mathrm{pdf}$

Shkullaku, R. (2013). The relationship between self-efficacy and academic performance in the context of gender among albanian students. European Academic Research, 1(4), 467. Retrieved from http://www.euacademic.org/ UploadArticle/33.pdf

Spielberg, C. D. \& Díaz-Guerrero, R. (1975). Inventario de ansiedad: RasgoEstado. Ciudad de México, México, Manual Moderno 478.

Tenaw, Y. A. (2013). Relationship between self-efficacy, academic achievement and gender in analytical chemistry at DebreMarkos College of teacher education. African Journal of Chemical Education, 3(1), 3-28, Retrieved from https:/www.ajol.info/index.php/ajce/article/view/84850

Viciana, J., Cervelló, E. M., \& Ramírez, J. (2007). Effects of manipulating positive and negative feedback on goal orientation, perceived motivational climate, satisfaction, task choice, perception of ability, and attitude to physical education lessons. Perceptual and motor skills, 105(1), 67-82. https:// doi.org/10.2466/pms.105.1.67-82

Williams, J. D., \& Takaku, S. (2011). Gender, Writing Self-Efficacy, and Help Seeking. International Journal of Business, Humanities and Technology, 1(3), 46-54. https://doi.org/10.17239/jowr-2011.03.01.1 